\title{
Pelevelan Kemampuan Pemecahan Masalah Matematis Berdasarkan Taksonomi Solo
}

\author{
${ }^{1}$ Viki Dardianto Arico, ${ }^{2}$ Wahyudi \\ ${ }^{1,2}$ Prodi Pendidikan Matematika, Universitas Muhammadiyah Ponorogo \\ Email Korespondensi: viki.arico@gmail.com
}

\begin{abstract}
Problem-solving is the thought that students have in determining solutions to the problem at hand. The process of students finding solutions to problems is known as problem-solving abilities. Mathematical problem-solving ability is the ability to solve problems by paying attention to the elements needed in making a required solution strategy and having the ability to know the truth of a problem. This ability needs to be measured to determine the level of understanding of students in solving problems. SOLO taxonomy is student response in solving a problem to determine the level of ability students have. By using the SOLO taxonomy, student response rates were divided into 5, namely structural, uni structural, multi structural, relational, and extended abstract. This study uses literature review research to provide the leveling of mathematical problem-solving abilities based on the SOLO taxonomy. The results of data collection from various relevant sources, it can be seen that the SOLO taxonomy can make it easier to determine the level of mathematical problem-solving ability through the responses possessed by students.
\end{abstract}

Keywords: problem-solving abilities; SOLO taxonomy

\begin{abstract}
Abstrak. Pemecahan masalah merupakan pemikiran yang dimiliki siswa dalam menentukan solusi-solusi dari masalah yang dihadapi. Proses siswa dalam menemukan solusi terhadap masalah maka dinamakan sebagai kemampuan pemecahan masalah. Kemampuan pemecahan masalah matematis merupakan kemampuan untuk memecahkan masalah dengan memperhatikan unsur-unsur yang diperlukan dalam membuat suatu strategi pemecahan yang dibutuhkan dan memeiliki kemampuan untuk mengetahui kebenaran dari suatu masalah. Kemampuan ini perlu diukur untuk megetahui tingkat pemahaman siswa dalam memmecahkan masalah. Taksonomi SOLO adalah respon siswa dalam memecahkan suatu masalah untuk mengetahui tingkat kemampuan yang dimiliki siswa. Dengan menggunakan taksonomi SOLO tingkat respon siswa dibagi menjadi 5 yaitu prastruktural, unistruktural, multistruktural, relasional dan extended abstrack. Penelitian ini menggunakan penelitian kajian pustaka dengan tujuan memberikan tentang pelevelan kemampuan pemecahan masalah matematis berdasarkan taksonomi SOLO. Hasil pengumpulan data dari berbagai sumber yang relevan maka dapat diketahui bahwa taksonomi SOLO dapat memudahkan dalam mengetahui tingkat kemampuan pemecahan masalah matematis melalui respon yang dimiliki oleh siswa.
\end{abstract}

Kata Kunci : kemampuan pemecahan masalah, taksonomi SOLO

\section{PENDAHULUAN}

Matematika merupakan salah satu mata pelajaran yang diajarkan kepada siswa mulai dari pendidikan sekolah dasar, sekolah menengah pertama, sekolah menengah atas, sampai jenjang perguruan tingggi. Matematika sendiri merupakan mata pelajaran yang sering ditakuti bagi sebagian besar siswa, hal ini dikarenakan matematika termasuk mata pelajaran yang dianggap siswa sulit. Banyak

Jurnal Ilmu Sosial dan Pendidikan siswa yang berpikir matematika adalah mata pelajaran yang hanya menghafal saja, akan tetapi sebenarnya menuntut siswa untuk berpikir kreatif, kritis, sistematis, analitis dan logis. Sehingga siswa mengalami kesalahan dalam pemecahan masalah matematika.

Kemampuan pemecahan masalah sangat penting dimiliki siswa, namun kenyataan di lapangan kemampuan pemecahan masalah matematis siswa masih rendah 
Jurnal Ilmu Sosial dan Pendidikan

http://ejournal.mandalanursa.org/index.php/JISIP/index

Terakreditasi Peringkat 5 (No. SK: 85/M/KPT/2020)
Vol. 5. No. 1 Januari 2021

p-ISSN: 2598-9944 e- ISSN: 2656-6753
(Kharisma dan Sugiman, 2017: 143). Banyaknya siswa yang masih mengalami kesalahan dalam memecahkan masalah matematika untuk kegiatan pembelajaran. Kesulitan dalam menyelesaikan masalah matematika ditandai dengan adanya kesalahan dalam menyelesaikan masalah matematika. Menurut (Kharisma dan Sugiman, 2017: 143). Kemampuan pemecahan masalah siswa menjadi salah satu komponen utama dalam aktivitas pemecahan masalah dalam kegiatan pembelajaran.

Dalam kegiatan pembelajaran matematika siswa menghadapi kesulitan dalam memecahkan permasalahan matematika seperti mengubah kata-kata tertulis ke dalam operasi matematika (Widyawati, Afifa, dan Resbiantoro, 2018). Kesalahan yang dialami siswa dalam memecahkan masalah dapat diidentifikasi melalui tes untuk dapat mengungkapkan kesalahan apa yang dilakukan siswa pada saat proses pengerjaan, salah satunya dengan tes pemecahan masalah berdasarkan taksonomi SOLO.

Dalam dunia pendidikan level berpikir siswa dapat diukur meggunakan taksonomi. Taksonomi yang termasuk cocok dalam mengatur berbagai jenis hasil pembelajaran oleh siswa adalah taksonomi SOLO. Dari (Kamilia, 2018) Biggs dan Collis, Collis dan Romberg menyatakan bahwa struktur respon siswa yang terlihat pada setiap tingkat adalah ketepatan dalam menggunakan operasi-operasi serta meningkat kompleksitasnya yang menjadi dasar dalam penyusunan formulasi siklus baelajar taksonomi SOLO. Menurut (FEBRYANI PUTRI, 2013) dalam Agustina (2016: 2) taksonomi SOLO digunakan untuk mengukur kemampuan siswa dalam merespon suatu masalah yang diklasifikasikan menjadi lima level yang berbeda yang bersifat hirearkis yaitu prastruktural, unistruktural, multistruktural, relasional dan extended abstract. Pada level prastruktural, siswa belum memahami soal yang diberikan sehingga cenderung tidak memberikan jawaban. Pada level unistruktural siswa menggunakan sepenggal informasi yang jelas dan langsung dari soal untuk menyelesaikan masalah. Pada level multistruktural siswa menggunakan dua penggal informasi atau lebih dari soal untuk menyelesaikan masalah dengan tepat tetapi tidak dapat menggabungkannya secara bersamasama. Pada level relasional, siswa berpikir menggunakan dua penggal atau lebih informasi pada soal dan menghubungkannya untuk menyelesaikan masalah dengan tepat. Sedangkan pada level extended abstract, Siswa berpikir induktif dan deduktif, menggunakan dua penggal informasi atau lebih dari soal yang diberikan dan menghubungkan informasiinformasi tersebut kemudian menarik kesimpulan untuk membangun suatu konsep baru dan menerapkannya.

\section{METODE}

Metode yang digunakan untuk artikel ini adalah studi literature yang dikaji dari berbagai sumber dan artikel. Pengumpulan data menggunakan metode observasi yang memuat data yang diambil dari kata, klausa, dan kalimat dari sumber pustaka yang berkaitan mengenai kemampuan pemecahan masalah matematis bedasarkan Taksonomi SOLO. Sebagaimana disampaikan (Zed, 2004: 3) bahwa penelitian pustaka ialah serangkaian kegiatan yang berkenaan dengan metode pengumpulan data pustaka, membaca dan mencatat serta mengolah bahan penelitian. Penelitian kepustakaan adalah teknik pengumpulan data dengan mengadakan studi penelaahan terhadap buku-buku, literaturliteratur, catatan-catatan, dan laporan-laporan yang ada hubungannya dengan masalah yang dipecahkan (Nazir, 2003). Kemudian teknik analisis yang digunakan adalah reduksi data, penyajian data dan penarikan kesimpulan.

\section{HASIL DAN PEMBAHASAN \\ Kemampuan Pemecahan Masalah Matematis}

Menurut Robert L. Solso (Ratnasari, 2014) pemecahan masalah adalah suatu pemikiran langsung yang dilakukan siswa untuk menemukan solusi suatu masalah yang spesifik. Sedangkan (Siwono, 2008) berpendapat bahwa pemecahan masalah adalah suatu proses atau upaya individu dalam merespon kendala ketika metode yang digunakan dalam menentukan jawaban belum 
Jurnal Ilmu Sosial dan Pendidikan

http://ejournal.mandalanursa.org/index.php/JISIP/index

Terakreditasi Peringkat 5 (No. SK: 85/M/KPT/2020)

tampak jelas. Dengan demikian proses berpikir individu secara langsung dan terarah dalam pemecahan masalah adalah untuk menemukan jawaban yang tepat dari suatu masalah. Kesumawati (Chotimah, 2014) menyatakan kemampuan pemecahan masalah matematis adalah kemampuan megidentifikasi unsur-unsur yang diketahui, ditanyakan, dan kecukupan unsur yang diperlukan, mampu membuat atau menyusun model matematika, dapat memilih dan mengembangkan strategi pemecahan, mampu menjelaskan dan memeriksa kebenaran jawaban yang diperoleh.

Menurut Polya (Wardhani \& Dkk, 2010) aspek kemampuan memecahkan masalah dibagi menjadi empat yaitu sebagai berikut: 1) Memahami masalah, melibatkan pendalaman situasi masalah, melakukan pemilahan fakta-fakta, menentukan hubungan diantara fakta-fakta dan membuat formulasi pertanyaan masalah. Setiap masalah yang tertulis, Bahkan yang paling sederhana juga harus dibaca berulang kali dan dipelajari dengan cermat informasi yang terkandung dalam pertanyaan. 2) Membuat rencana pemecahan masalah, upaya dalam mengembangkan rencana solusi dengan mempertimbangkan struktur masalah dan pertanyaan yang harus dijawab. Dalam proses pembelajaran pemecahan masalah, siswa harus memiliki pengalaman dalam menerapkan strategi pemecahan masalah. 3) Melaksanakan rencana pemecahan masalah, untuk mencari solusi yang tepat, rencana yang telah didapat harus digunakan dengan hatihati. Diagram, tabel atau urutan dibangun secara seksama sehingga si pemecah masalah tidak akan bingung. Jika muncul ketidakkonsistenan ketika melaksanakan rencana, proses harus diteliti kembali untuk mencari letak kesulitan masalah. 4) Melihat (mengecek) kembali, Selama melakukan pengecekan, solusi masalah harus dipertimbangkan. Solusi harus tetap cocok terhadap akar masalah meskipun kelihatan tidak beralasan.

Menurut (Kaina \& Arifin, 2018) kemampuan pemecahan masalah merupakan salah satu kemampuan tingkat tinggi dalam
Vol. 5. No. 1 Januari 2021

p-ISSN: 2598-9944 e- ISSN: 2656-6753

matematika. Hal ini dikarenakan ketika seseorang memecahkan masalah, berarti dia telah mampu melalui serangkaian proses. Adapun factor-faktor yang dapat meningkatkan kemampuan memecahkan masalah matematika adalah:

1) Kemampuan memahami ruang lingkup masalah dan mencari informasi yang relevan untuk mencapai solusi, artinya siswa harus dapat membedakan informasi yang relevan dan yang tidak relevan dengan masalah yang dihadapinya. Kemudian, faktor kemampuan dalam memilih pendekatan pemecahan masalah yang cocok.

2) Kemampuan memilih pendekatan pemecahan masalah atau strategi pemecahan masalah, yangi dipengaruhi oleh keterampilan siswa dalam mengungkapkan masalah dan struktur pengetahuannya.

3) Keterampilan berpikir dan bernalar siswa yaitu kemampuan berpikir yang fleksibel dan objektif yang merupakan kemampuan siswa dalam memecahkan masalah terkait dengan pengetahuan yang dimilikinya, yaitu pengetahuan yang tersimpan dalam ingatannya, dan bagaimana mengembangkan pengetahuan tersebut.

4) Dalam proses pemecahan masalah, kemampuan metakognitif atau kemampuan memantau dan mengontrol sangat penting, artinya pada tahap pemecahan masalah siswa menyadari bagaimana dan mengapa mereka melakukan hal tersebut, siswa juga menyadari langkah yang diambilnya apakah berjalan dengan baik atau menemui kendala sehingga dapat mendorong siswa untuk mempertimbangkan alternatif lain atau mencoba kembali memahami masalahnya lagi.

5) Persepsi matematika diartikan sebagai sikap positif terhadap ciri-ciri matematika yang membutuhkan pemikiran sistematis, analitis, dan logis.

6) Sikap siswa, mencakup kepercayaan diri, tekad, kesungguh-sungguhan dan 
ketekunan dalam mencari pemecahan masalah

7) latihan-latihan, hal ini diperlukan untuk mendapatkan pembiasaan dalam pemecahan masalah matematis. Semakin sering seseorang dalam berlatih, maka semakin baik kemamapuan pemecahan masalah matematisnya.

\section{Taksonomi SOLO}

Taksonomi SOLO dikembangkan oleh Biggs dan Collis pada tahun 1982. Biggs dan Collis mengklasifikasikan taksonomi SOLO berdasarkan lima level yaitu prastruktural, unistruktural, multistruktural, relasional, dan extended abstrak (Biggs, 2007; Brabrand, 2009; Kuswana, 2012). Klasifikasi ini didasarkan pada keragaman kemampuan berpikir pemecahan masalah siswa saat merespon pertanyaan yang disajikan. (Biggs \& Collis, 1982) menjelaskan bahwa kemampuan yang dimiliki siswa dalam menyelesaikan masalah matematika, guru dapat menentukannya secara individu maupun kelompok. Selain itu, Watson dalam (Kuswana, 2012) juga berpendapat bahwa taksonomi SOLO dapat digunakan sebagai alat yang mudah dan sederhana untuk menyusun dan menentukan tingkat kesulitan atau kompleksitas suatu pertanyaan di dalam soal.

Menurut (Hamdani, 2009) perbedaan taksonomi SOLO dengan taksonomi Bloom yang biasa digunakan sebagai acuan untuk mengembangkan tujuan kurikulum dalam sistem pendidikan di Indonesia bergantung pada cara pandang dalam melihat tujuan pembelajaran. Dalam mengklasifikasikan hasil belajar siswa berdasarkan cara berpikir siswa dapat menggunakan taksonomi Bloom, namun untuk lebih spesifik dalam mengklasifikasikan cara berpikir siswa yang dilihat dari respon siswa ketika memberikan perlakuan untuk membaca dan menjawab pertanyaan soal, maka dapat digunakan taksonomi SOLO. Taksonomi Solo merupakan salah satu taksonomi tujuan pembelajaran, yang membedakan dengan taksonomi lainnya adalah cara pandang terhadap tujuan pendidikan. Biggs \& Collis, mendesain taksonomi SOLO (Structure of Observed
Learning Outcomes) sebagai suatu alat evaluasi tentang kualitas respons siswa terhadap suatu tugas. Jadi, Taksonomi Solo adalah klasifikasi respon siswa mengenai struktur hasil belajar siswa. Menurut Biggs dan Collis bahwa level respon seorang siswa akan berbeda antara suatu konsep dengan konsep lainnya`

Taksonomi SOLO dapat membantu usaha menggambarkan tingkat kompleksitas pemahaman siswa tentang subjek, melalui lima level respons, dan diklaim dapat diterapkan di setiap wilayah subjek (Kuswana, 2012). Taksonomi SOLO mengelompokkan respon dari 5 level berbeda meliputi:

1) Prestructural: tidak memahami maksud pertanyaan, dia memberikan sebuah jawaban bahkan tanpa berurusan dengan permasalahan, dengan kata lain siswa gagal terlibat dalam permasalahan.

2) Unistructual: hanya fokus pada salah satu atau beberapa informasi relevan yang ada untuk menyediakan sebuah respons pada realitas konkret yang terlibat langsung dengan permasalahan. Informasinya didapat dari salah satu skema atau dari diagram yang ada. Dengan kata lain, sebuah simpulan cepat (jawaban) pun dicapai atas dasar pemakaian minimal dan informasinya yang ada. Misalnya, siswa menggunakan dan mengacu pada objek konkret (gambar) yang diberikan untuk menemukan hubungan berikutnya dari pola yang ada.

3) Multistructural: informasi yang digunakan lebih relevan yang ada, mungkin digunakan sebagai resep dimana sperangkat instruksi dan diikuti dalam rangkaian untuk memecahkan masalah. Misalnya, siswa mulai mengidentifikasi hubungan antara variabel-variabel dari pola dan mampu untuk menggambarkan bagaimana bergerak dari salah satu hubungan dalam sebuah rangkaian menuju ke hubungan berikutnya. Siswa mampu untuk melihat polayang diberikan sebagai proses yang berturutturut.

4) Relational: mampu mengintegrasikan semuan aspek dari informasi yang sada satu sama lain ke dalam sebuah struktur yang logis. Dengan kata lain. Informasi yang ada 
tidak memadai untuk memecahkan masalah dengan segera. Hal ini harus secara hati-hati saling dikaitkan untuk menghasilkan sebuah solusi yang memuaskan. Misalkan, siswa mampu menggeneralisasikan hubungan dari pola secara simbolis yang didasarkan pada sebuah informasi dari pola yang ada.

5) Extended abstract: menggeneralisasikan struktur ke dalam sebuah situasi yang lebih abstrak dan baru. Hal ini memungkinkan untuk menggeneralisasikan pada sebuah topik atau area yang baru. Contoh, siswa mampu mengintepretasi prinsip umum abstrak dari informasi yang ada dan menggunakan penalaran deduktif untuk membentuk suatu solusi alternative dari pola yang baru.

\section{Pelevelan pemecahan masalah matematis berdasarkan taksonomi solo}

Berdasarkan uraian diatas dapat diketahui bahwa kemampuan pemecahan masalah matematis merupakan pemikiran atau proses yang dilakukan oleh siswa selama menyelesaikan suatu masalah untuk menemukan solusinya. Proses kemampuan pemecahan masalah siswa seperti memahami suatu masalah yang dihadapi dengan mencari informasi-informasi yang dibutuhkan dengan menggunakan kemampuan mereka sendiri tanpa bantuan dari orang lain. Informasi yang didapat tersebut dapat digunakan untuk memilih pendekatan atau strategi yang cocok, strategi yang dimaksud seperti mencari pola dari masalah tersebut. Disini ketarmpilan siswa dapat dilihat dari pengetahuan mereka ketika memilih strategi yang dipakai. Ketika penggunaan strategi yang dipilih tersebut memberikan solusi masalah dan siswa menyadari tahapan-tahapan, langkah-langkah yang dipakai menuju kepada solusi yang benar dan memiliki alternative lain dari masalah tersebut maka siswa tersebut memiliki kemampuan matakognitif.

Kemampuan pemecahan masalah matematis tersebut juga dapat diukur menggunakan beberapa cara salah satunya yaitu dengan menggunakan taksonomi SOLO. Penggunaan taksonomi SOLO sebagai alat ukurnya lebih disarankan dikarenakan memiliki kemudahan dalam mengukurnya, hanya dengan menggunakan hasil dari pemecahan masalah yang dilakukan siswa maka dapat mengetahui apakah siswa termasuk kedalam level prastruktural, unistruktural, multicultural, ralasional atau extended abstract.

Pada level prastruktural informasi yang didapat siswa hanya sedikit bahkan tidak berhubungan serta tidak relevan, sehingga terdapat sebuah konsep yang tidak memiliki makna apapun. Konsep yang muncul dari informasi tersebut bersifat personal, subjektif dan tidak diatur secara internal. Maka siswa pada level ini memiliki hasil pemecahan masalah yang belum tepat. Pada level unistruktural mulai terdapat hubungan yang jelas antara konsep-konsep yang dimiliki siswa akan tetapi inti dari konsep tersebut belum dipahami secara luas. Dalam memecahkan masalah siswa sudah memiliki prosedur lengkap akan tetapi terdapat keterbatasan hasil yang diperoleh. Keterbatasan keterbatasan tersebut terjadi dikarenakan siswa hanya memilih satu informasi dari beberapa informasi yang tersedia. Pada level multicultural siswa sudah mulai memahami komponen-kompenen yang ada namun hal tersebut masih bersifat terpisah satu sama lain sehingga belum membentuk pemahaman secara komprehensif serta kemampuan metakognitif belum tampak dalam level ini. Siswa memiliki keterhubungan dalam informasi-informasi yang didapat meskipun belum tepat. Pada level relasional siswa telah menghubungkan antara fakta dengan teori atau informasi yang didapat. Sudah memiliki pemahaman tentang beberapa komponen yang menjadi satu kesatuan konsep serta memahami peran bagian-bagian bagi keseluruhan dan mengaplikasikan menjadi sebuah konsep. Beberapa nformasi yang didapat juga sudah tepat. Pada level extended abstract konsep yang di dapat siswa tidak sebatas konsep yang diberikan pada suatu masalah akan tetapi memiliki keterhubungan konsep diluar konsep yang diberikan. Dapat membuat generalisasi dan melakuakan perumpamaan-perumpamaan pada situasi spesifik. Keterhubungan beberapa informasi yang sudah tepat. Dapat dikatakan bahwa siswa pada level ini sudah menguasi 
Jurnal Ilmu Sosial dan Pendidikan

http://ejournal.mandalanursa.org/index.php/JISIP/index

Terakreditasi Peringkat 5 (No. SK: 85/M/KPT/2020)

materi sehingga dioperoleh hasil pemecahan masalah yang tepat.

\section{KESIMPULAN}

Berdasarkan telaah pustaka dapat disimpulkan bahwa dalam pembelajaran matematika siswa tidak hanya menghafal tetapi juga dilatih untuk berpikir kreatif kritis sistematis analitis dan logis sehingga matematika diajarkan di semua jenjang pendidikan. Namun masih banyak siswa yg masih memiliki pemahaman kurang terhadap pemecahan suatu masalah. agar dapat mengungkapkan pemahaman siswa dalam proses pembelajaran matematika maka dapat digunakan tes berdasarkan taksonomi solo, karena dalam taksonomi solo terdapat 5 level berbeda yaitu Prestructural, Unistructual, Multistructural, Relational, Extended abstract: dimana level 5 level tersebut dapat digunakan untuk menganalisis pemahaman yang dimiliki siswa saat ini.

\section{DAFTAR PUSTAKA}

Biggs, J., \& Collis, K. (1982). Evaluating The Quality of Learning The SOLO. Taxonomi (Structure of The Observed Learning Outcome) New York: Academic Press.

Chotimah, N. (2014). Pengaruh Model Pembelajaran Generatif (MPG) Terhadap Kemampuan Pemecahan Masalah dan Disposisi Matematis Siswa di Kelas X Pada SMA Negeri 8 Palembang. Skripsi. Universitas PGRI Palembang.

FEBRYANI PUTRI, L. (2013). Identifikasi Kemampuan Matematika Siswa Dalam Memecahkan Masalah Aljabar Di Kelas Viii Berdasarkan Taksonomi Solo. MATHEdunesa, 2(1), 29-30.

Hamdani, A. (2009). Pengembangan Sistem Evaluasi Pembelajaran Pendidikan Agama Islam Berbasis Taksonomi SOLO. Jurnal Pendidikan Islam, 01.

Kaina, N., \& Arifin, Z. (2018). Pemecahan Masalah Matematis Berdasarkan Prosedur Newman. Procediamath, 2, $1-10$.

Kamilia, I. D., Sugiarti, T., Trapsilasiwi, D.,
Vol. 5. No. 1 Januari 2021

p-ISSN: 2598-9944 e- ISSN: 2656-6753

Susanto, \& Hobri. (2018). Analisis Level Berpikir Siswa Berdasarkan Taksonomi Solo Dalam Menyelesaikan Soal Cerita SPLDV Ditinjau Dari Tipe Kepribadian Florence Littuer. Kadikma, 9(2), 165174.

Kharisma, J. Y. (2017). Pengembangan Bahan Ajar Matematika Berbasis Masalah Berorientasi Kemampuan Pemecahan Masalah dan Prestasi Belajar Matematika Developing ProblemBased Mathematics Instructional Materials Oriented to Students , Mathematics Problem Solving Skill And Mathemat. Jurnal Pendidikan Matematika Dan Sains, 1866(2), 142-151.

Kuswana, S. (2012). Taksonomi Kognitif Perkembangan Ragam Berfikir. Bandung: PT Remaja Rosdakarya.

Nazir. (2003). Metode Penelitian. Ghalia Indonesia.

Ratnasari, D. (2014). Pengaruh Model Pembelajaran Generatif Lembar Pengesahan Pembimbing Skripsi.

Siwono, \& Tatag, Y. E. Model Pembelajaran Matematika Berbasis Pengajuan Dan Penecahan Masalah Untuk Meningkatkan Kemampuan Berpikir Kreatif. Unesa University.

Wardhani, S., \& Dkk. (2010). Pembelajaran Kemampuan Pemecahan Masalah Matematika Di SMP. In PPPPTK Matematika.

Widyawati, A., Septi, D., Afifah, N., \& Resbiantoro, G. (2018). Analisis Kesalahan Siswa Dalam Memecahkan Masalah Lingkaran Berdasarkan Taksonomi Solo Pada Kelas Viii. Jurnal Pendidikan Matematika Dan Sains, 6(1), 1-9.

Zed, M. (2004). Metode Penelitian Kepustakaan. Yayasan Obor Indonesia. 